\title{
Homogenization of 7075 and 7049 Aluminium Alloys Intended for Extrusion Welding
}

\author{
Antoni Woźnicki ${ }^{1, *}$, Beata Leszczyńska-Madej ${ }^{2}{ }^{\circledR}$, Grzegorz Włoch ${ }^{2}$, Justyna Grzyb ${ }^{2}$, Jacek Madura ${ }^{2}$ \\ and Dariusz Leśniak ${ }^{2}$ \\ 1 Aptiv Services Poland S.A., 30-399 Kraków, Poland \\ 2 Faculty of Non-Ferrous Metals, AGH University of Science and Technology, 30-059 Kraków, Poland; \\ bleszcz@agh.edu.pl (B.L.-M.); gwloch@agh.edu.pl (G.W.); jgrzyb@agh.edu.pl (J.G.); \\ madura@agh.edu.pl (J.M.); dlesniak@agh.edu.pl (D.L.) \\ * Correspondence: antoni.woznicki@gmail.com
}

Citation: Woźnicki, A.; Leszczyńska-Madej, B.; Włoch, G.; Grzyb, J.; Madura, J.; Leśniak, D. Homogenization of 7075 and 7049 Aluminium Alloys Intended for Extrusion Welding. Metals 2021, 11, 338. https://doi.org/10.3390/ met11020338

Received: 26 November 2020 Accepted: 13 February 2021 Published: 17 February 2021

Publisher's Note: MDPI stays neutral with regard to jurisdictional claims in published maps and institutional affiliations.

Copyright: (c) 2021 by the authors. Licensee MDPI, Basel, Switzerland. This article is an open access article distributed under the terms and conditions of the Creative Commons Attribution (CC BY) license (https:// creativecommons.org/licenses/by/ $4.0 /)$.

\begin{abstract}
During the extrusion of aluminum alloys profiles using porthole dies, the temperature of the material in the welding chamber is one of crucial parameters determining the quality of longitudinal welds. In order to extend the permissible temperature range, the billets intended for this process should be characterized by the maximum attainable solidus temperature. Within the present work, the homogenization of AlZnMgCu alloys DC-cast (Direct Chill-cast) billets was investigated, with the aim of solidus temperature maximization. Conditions of soaking and cooling stages were analyzed. The materials were homogenized in laboratory conditions, and the microstructural effects were evaluated on the basis of DSC (Differential Scanning Calorimetry) tests and SEM/EDS (Scanning Electron Microscopy/Energy-Dispersive Spectroscopy) investigations. For all examined alloys, the unequilibrium low-melting microstructure components were dissolved during soaking, which led to the significant solidus temperature increase, in comparison to the as-cast state. The values within the range of $525-548^{\circ} \mathrm{C}$ were obtained. In the case of alloy with highest $\mathrm{Cu}$ concentration, the application of two-step soaking was necessary. In order to take advantage of the high solidus temperature obtained after soaking, the cooling rate from homogenization must be controlled, and the effective cooling manner is strongly dependent on alloy composition. For high-Cu alloy, the solidus decreased, despite the fast cooling and the careful billets preheating being necessary.
\end{abstract}

Keywords: AlZnMgCu alloys; billets homogenization; solidus temperature; extrusion welding

\section{Introduction}

In current industrial practice, the extrusion with the use of porthole dies is commonly applied for aluminum as well as its low- and medium-strength alloys. However, there is a demand for hollow profiles with higher strength, and research efforts are aiming at an elaboration of similar technology for high-strength 2xxx, 5xxx, and Cu-containing 7xxx alloys $[1,2]$. Among parameters determining the quality of longitudinal welds, the temperature in the welding chamber is one of great importance [1,3-6]. The hard-deformable $\mathrm{Al}$ alloys, in particular those of 7xxx series with $\mathrm{Cu}$, are characterized by low solidus temperature [7], which becomes a factor significantly limiting the permissible temperature of material in the welding chamber. Thus, the careful selection of alloys' chemical composition as well as suitable billets preparation for extrusion are important steps in the elaboration of hard-deformable alloys extrusion technology.

The DC-cast billets of AlZnMgCu alloys are characterized by dendritic microstructure with numerous eutectics and particles. The commonly reported phases are the $\mathrm{M}-(\mathrm{Cu}$, $\mathrm{Zn}, \mathrm{Al})_{2} \mathrm{Mg}$, T-(Cu, Zn, $\left.\mathrm{Al}\right)_{49} \mathrm{Mg}_{32}, \mathrm{~S}-\mathrm{Al}_{2} \mathrm{CuMg}$, and Fe-bearing ones [8-13]. The nonequilibrium solidification during DC casting results in low billets solidus temperature, most often values in the range $470-480^{\circ} \mathrm{C}$ are noted $[9,14-16]$, but lower can also be found 
in the literature $[17,18]$. The solidus temperature can be increased by homogenization annealing; however, obtained effects are strongly dependent on process parameters.

The initial soaking temperature is limited by unequilibrium solidus temperature, because incipient melting, causing irreversible microstructural damage, must be avoided [9]. Thus, the first stage of soaking should be accomplished below $470{ }^{\circ} \mathrm{C}$. The $\mathrm{M}$ and $\mathrm{T}$ phases can be effectively dissolved in these conditions. However, the S-phase, often observed in the as-cast billets microstructure or forming and growing during initial stages of annealing [9, $13,19,20]$, is hard to redissolve, and it is frequently noted after homogenization at the mentioned temperature range [13-15]. In that situation, the billets solidus temperature increases slightly, but it is still below $500{ }^{\circ} \mathrm{C}$. The complete dissolution of the S-phase is in many cases obtained after multi-stage homogenization, when due to the rise of solidus temperature during the initial stage, the application of higher final soaking temperature is possible [14,21]. Although the microstructure evolutions taking place in AlZnMgCu billets during homogenization soaking are described in the literature for many alloy compositions, the values of solidus temperature, which can be obtained after homogenization with full dissolution of low melting structure components, are unfortunately reported rarely.

Another homogenization parameter influencing the solidus temperature of billets is a cooling rate after completed soaking. The billets of described alloys are usually slowly cooled after homogenization, which leads to the precipitation of phases showing limited solubility (e.g., $\mathrm{M}, \mathrm{T}$ ), depletion of solid solution from $\mathrm{Zn}, \mathrm{Mg}$, and $\mathrm{Cu}$, and lowering of flow stress as well as extrusion pressure. However, if cooling is very slow, the mentioned phases can be precipitated in a form of large particles, which are incapable for dissolution during billets preheating and extrusion. Their presence in the billets microstructure can cause unequilibrium incipient melting [9]. Similar effects are noted also for other $\mathrm{Al}$ alloys series $[22,23]$. Hence, taking advantage of obtaining a full dissolution of low melting microstructure components during homogenization heating and soaking is possible when the cooling rate is properly selected. This aspect of $\mathrm{AlZnMgCu}$ billets preparation for extrusion is also rarely described in the literature.

The mentioned lack of data regarding the attainable solidus temperature of AlZn$\mathrm{MgCu}$ alloys after homogenization results probably from the fact that the billets solidus temperature is not a crucial material property in the conventional solid products extrusion, where temperature in the deformation zone is usually lower. However, as it was already mentioned, the high solidus temperature is necessary for the selection of extrusion welding parameters. This work presents the results of investigations aimed at determining the homogenization conditions leading to obtaining the highest possible solidus temperature of $\mathrm{AlZnMgCu}$ alloys billets, which are intended for extrusion welding.

\section{Materials and Methods}

The billets, with the chemical composition presented in Table 1 and diameter of 100 $\mathrm{mm}$, were DC cast in semi-industrial conditions. Four alloys were investigated: three within EN AW-7075 and one within EN AW-7049 grade.

Table 1. The chemical composition of investigated alloys, mass percentage.

\begin{tabular}{ccccccccc}
\hline Alloy Denotation & Si & Fe & Cu & Mg & Cr & Zn & Ti & Zr \\
\hline 7075 alloy 1 & 0.08 & 0.16 & 1.22 & 2.08 & 0.21 & 5.14 & 0.02 & 0.15 \\
7075 alloy 2 & 0.08 & 0.17 & 2.02 & 2.50 & 0.20 & 5.94 & 0.02 & 0.15 \\
7075 alloy 3 & 0.10 & 0.21 & 1.54 & 2.39 & 0.20 & 5.89 & 0.02 & 0.15 \\
7049 alloy 4 & 0.11 & 0.23 & 1.57 & 2.36 & 0.20 & 8.02 & 0.02 & 0.16 \\
\hline
\end{tabular}

The specimens with dimensions of $10 \times 20 \times 20 \mathrm{~mm}^{3}$, intended for examination in the as-cast state as well as for laboratory homogenization experiments, were sectioned from obtained billets.

At the first stage of work, the materials in the as-cast state were subjected to DSC (Differential Scanning Calorimetry) analyses as well as microstructure observations. The DSC 
tests were performed using a Mettler Toledo $821^{\mathrm{e}}$ heat flux type calorimeter (Greifensee, Switzerland). The disc-shaped samples were inserted in ceramic pans into the cell with the temperature of $390^{\circ} \mathrm{C}$ and heated $20^{\circ} \mathrm{C} / \mathrm{min}$ to the temperature of $700^{\circ} \mathrm{C}$ in Ar atmosphere. The solidus temperature and heat of the incipient melting reactions were determined.

The specimens intended for microstructure examination were mounted in conductive resin and mechanically ground and polished using in sequence abrasive papers, diamond suspensions, and colloidal silica suspension. The billets microstructure was examined using LM (light microscopy) and SEM/EDS (Scanning Electron Microscopy/Energy-Dispersive Spectroscopy). The specimens intended for LM observations were etched with Keller reagent and examined using Olympus GX 51 microscope (Tokyo, Japan). The SEM/EDS analyses were performed on non-etched specimens using a Hitachi SU-70 scanning electron microscope (Tokyo, Japan) equipped with a Thermo Scientific EDS system (Thermo Fisher Scientific, Waltham, MA, USA). EDS analyses were applied to determine the chemical composition of the observed eutectic areas or particles and to measure main alloying elements content in the dendrites interiors.

At the second stage of work, soaking parameters were examined. The conditions of laboratory homogenization experiments were selected on the basis of literature data $[9,14,20,21]$, earlier investigations, and the results of DSC tests of alloys in the as-cast state. The heat treatment experiments were accomplished using a Nabertherm forced convection chamber furnace. Three homogenization schemes were applied:

1. The standard homogenization with soaking at $465{ }^{\circ} \mathrm{C}$

2. The high-temperature homogenization with two soaking stages at 465 and $475^{\circ} \mathrm{C}$

3. The high-temperature homogenization with two soaking stages at 465 and $485^{\circ} \mathrm{C}$.

In all cases, materials were heated from room temperature to $465^{\circ} \mathrm{C}$ for $10 \mathrm{~h}$. A similar heating rate, about $40{ }^{\circ} \mathrm{C} / \mathrm{h}$, was applied during heating between soaking stages. After completed soaking, specimens were quenched in water. The details of the homogenization experiments performed in the second stage of the work are presented in Table 2.

Table 2. Laboratory homogenization conditions applied in stage 2.

\begin{tabular}{ccccc}
\hline Scheme Denotation/Homogenized Alloys & Heating 1 & Soaking 1 & Heating 2 & Soaking 2 \\
\hline $\begin{array}{c}\text { 1-standard homogenization/ } \\
\text { all alloys }\end{array}$ & $10 \mathrm{~h}$ & $0,2,4,8,12,16,20,24 \mathrm{~h}^{1}$ & - & - \\
$\begin{array}{c}\text { 2-high-temperature } \\
\text { homogenization/alloys 2 and 3 }\end{array}$ & $10 \mathrm{~h}$ & $465^{\circ} \mathrm{C} / 2 \mathrm{~h}$ & $15 \mathrm{~min}$. & $475{ }^{\circ} \mathrm{C} / 0,2,4,8 \mathrm{~h}$ \\
3-high-temperature homogenization/alloy 4 & $10 \mathrm{~h}$ & $465^{\circ} \mathrm{C} / 12 \mathrm{~h}$ & $30 \mathrm{~min}$. & $485{ }^{\circ} \mathrm{C} / 0,2,4,8 \mathrm{~h}$ \\
\hline
\end{tabular}

${ }^{1}$ - In the case of alloy 1 , soaking for up to $8 \mathrm{~h}$ was applied.

At the third stage, the influence of cooling rate from the homogenization temperature, on the billets of alloys 1, 2, and 4 microstructure, was investigated. Specimens were subjected to homogenization with soaking conditions selected on the basis of stage 2 results and cooled to room temperature in three ways. The average cooling rates in the temperature range from 465 or 475 to $200{ }^{\circ} \mathrm{C}$, estimated on the basis of specimens temperature measurements during cooling cycles, were about 500, 120, and $60^{\circ} \mathrm{C} / \mathrm{h}$.

Materials after all homogenization experiments were subjected to DSC tests. In stage 2, they were used for the analysis of low-melting microstructure components dissolution. In stage 3, the DSC runs were applied in order to evaluate the precipitated particles dissolution ability during rapid heating. On the basis of the obtained DSC results, specimens for microstructure observations were selected. The DSC analyses as well as the microstructure observations of homogenized alloys were performed in the manner described above. 


\section{Results}

\subsection{As-Cast Alloys}

Regarding the DSC curves of all investigated alloys in the as-cast state, the incipient melting peaks are observed (Figure 1). The determined onset temperature values, indicating the unequilibrium solidus temperature of a given alloy, are within the range of $479-484{ }^{\circ} \mathrm{C}$. The incipient melting heat varies from about 6 to about $12 \mathrm{~J} / \mathrm{g}$ (Table 3).
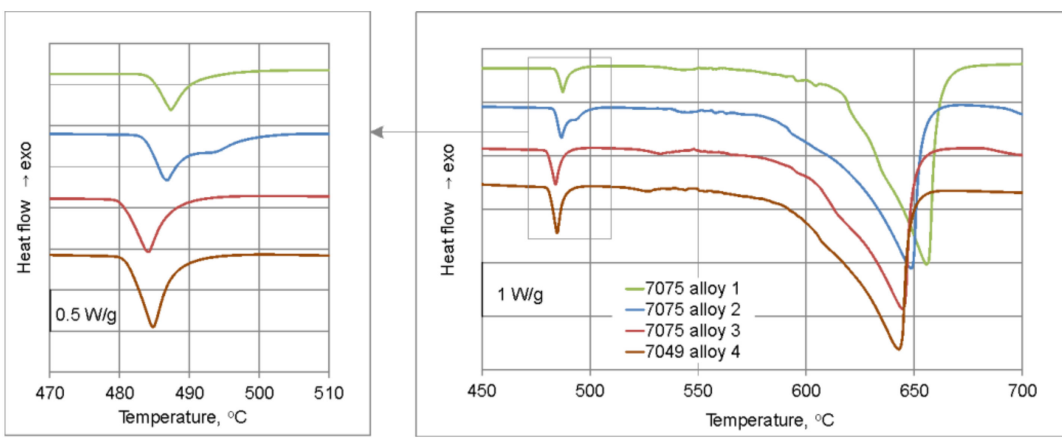

Figure 1. DSC curves of alloys in the as-cast state.

Table 3. DSC test results of as-cast alloys.

\begin{tabular}{ccc}
\hline Alloy & Solidus Temperature, ${ }^{\circ} \mathbf{C}$ & Incipient Melting Heat, J/g \\
\hline 7075 alloy 1 & 484.0 & 6.1 \\
7075 alloy 2 & 482.6 & 11.9 \\
7075 alloy 3 & 479.1 & 9.2 \\
7049 alloy 4 & 479.6 & 11.8 \\
\hline
\end{tabular}

In the microstructure of as-cast billets of all investigated alloys, the solid solution dendrites with numerous eutectic areas and particles located at dendrites/grains boundaries are observed. In the dendrites interiors, a significant microsegregation of alloying additions is noted (Figure 2).

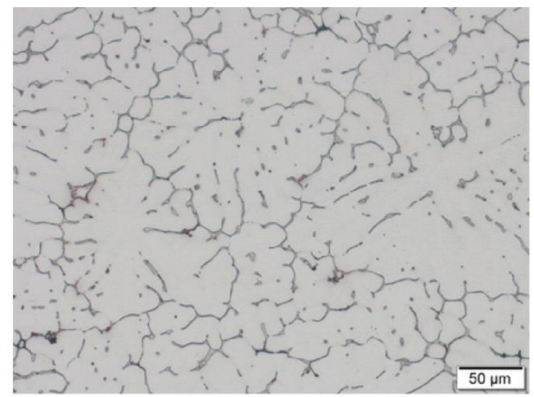

(a)
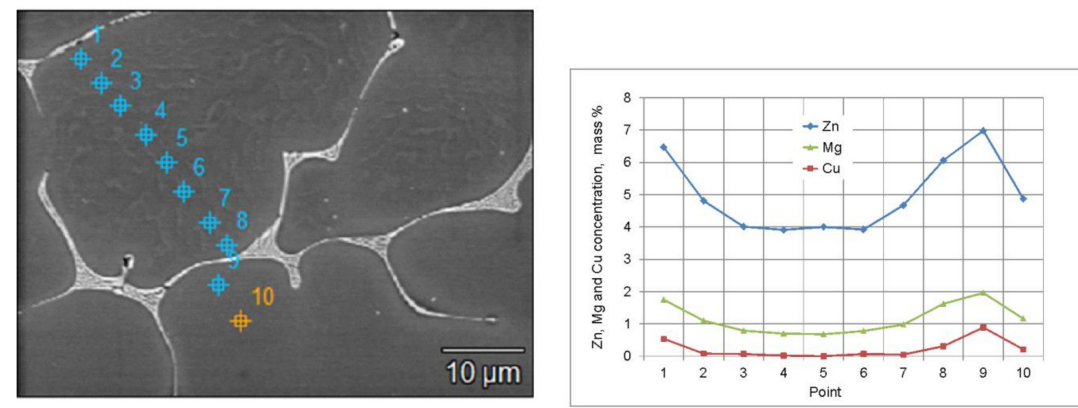

(b)

Figure 2. Microstructure of 7075 alloy 3 in the as-cast state: (a) optical microscope photograph; (b) SEM image with marked analysis points and distribution of main additions across dendrite. 
Based on SEM/EDS microanalyses results, one can distinguish the following microstructure components, besides solid solution (Figure 3):

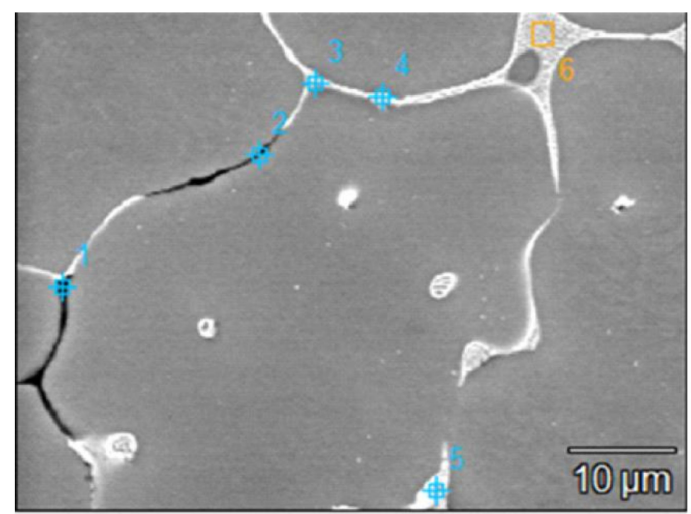

\begin{tabular}{|c|c|c|c|c|c|c|c|}
\hline \multicolumn{7}{|c|}{ Elements concentration, at. \% } \\
\hline Area & $\mathrm{Mg}$ & $\mathrm{Al}$ & $\mathrm{Si}$ & $\mathrm{Cr}$ & $\mathrm{Fe}$ & $\mathrm{Cu}$ & $\mathrm{Zn}$ \\
\hline 1 & 34.9 & 43.1 & 20.4 & & & 0.4 & 1.2 \\
\hline 2 & 27.7 & 56.1 & 14.3 & & 0.1 & 0.3 & 1.6 \\
\hline 3 & 1.8 & 79.0 & 0.3 & 0.4 & 13.0 & 4.1 & 1.4 \\
\hline 4 & 1.8 & 79.5 & 0.2 & 0.3 & 13.1 & 3.7 & 1.5 \\
\hline 5 & 6.3 & 70.9 & 1.3 & 0.6 & 8.7 & 6.5 & 5.6 \\
\hline 6 & 18.6 & 58.6 & & & & 10.1 & 12.7 \\
\hline
\end{tabular}

(a)

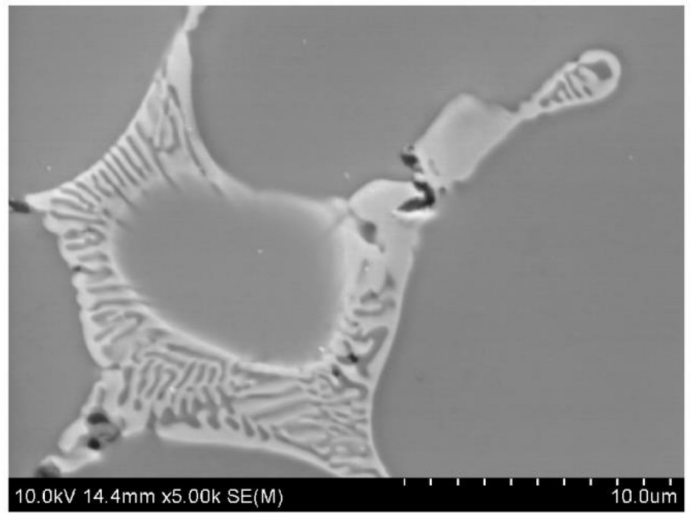

(b)

Figure 3. SEM/EDS (Scanning Electron Microscopy/Energy-Dispersive Spectroscopy) microanalyses results of eutectics and particles in the as-cast billets: (a) 7075 alloy 1; (b) 7049 alloy 4.

- $\quad$ Phase (or phases) containing $\mathrm{Al}, \mathrm{Zn}, \mathrm{Mg}$, and $\mathrm{Cu}$, forming eutectics and present as separated particles. As it was noted above, $\mathrm{M}$ and $\mathrm{T}$ are the phases that contain mentioned elements, but based on EDS microanalyses results, one cannot distinguish which of them, M or/and T, is present in the alloys microstructure [24]. Moreover, the S-phase formed during unequilibrium solidification can dissolve a noticeable amount of $\mathrm{Zn}$ [25].

- Particles containing mainly $\mathrm{Al}, \mathrm{Fe}$, and $\mathrm{Cu}$ (sometimes $\mathrm{Si}$ ).

- Phases rich in $\mathrm{Mg}$ and $\mathrm{Si}$, most probably $\mathrm{Mg}_{2} \mathrm{Si}$, are present in the form of separated particles and within eutectic areas.

Considering a similar unequilibrium solidus temperature for all investigated alloys, as well as microstructure examinations results and literature data, e.g., [9,12-15], one may expect that the predominantly observed phase containing $\mathrm{Al}, \mathrm{Zn}, \mathrm{Mg}$, and $\mathrm{Cu}$ causes an incipient melting of all alloys.

\subsection{Analysis of Soaking Conditions}

The exemplary DSC curves of alloys subjected to homogenization are shown in Figure 4, and in Figure 5, the changes of solidus temperature and incipient melting heat are presented. 


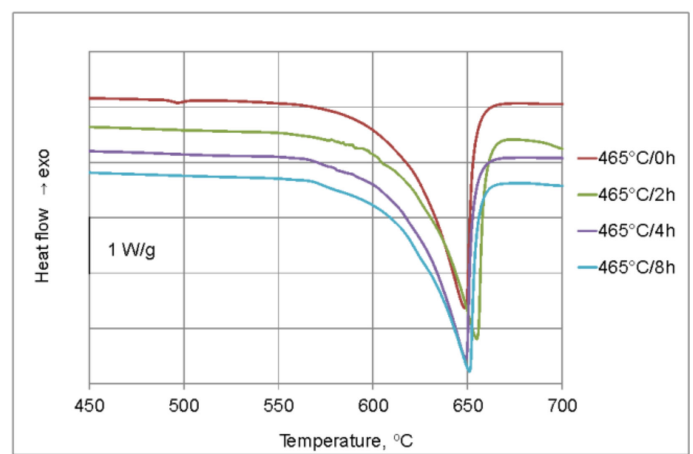

(a)

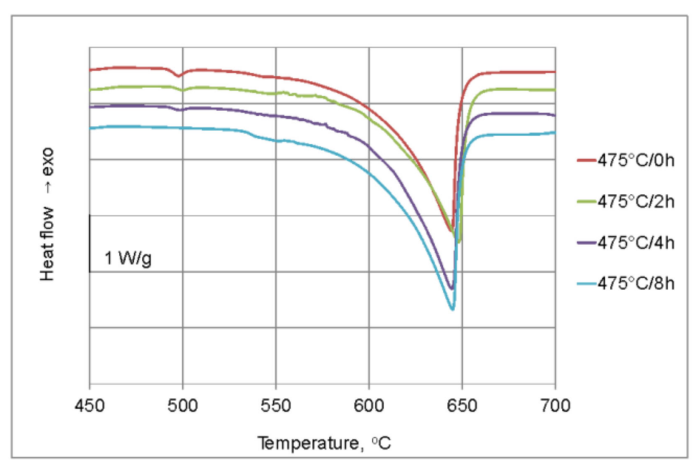

(b)
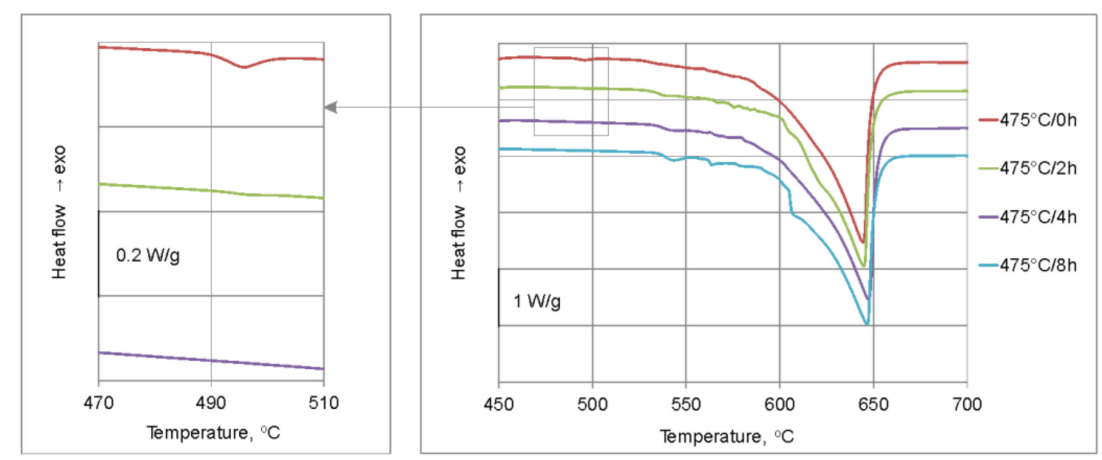

(c)
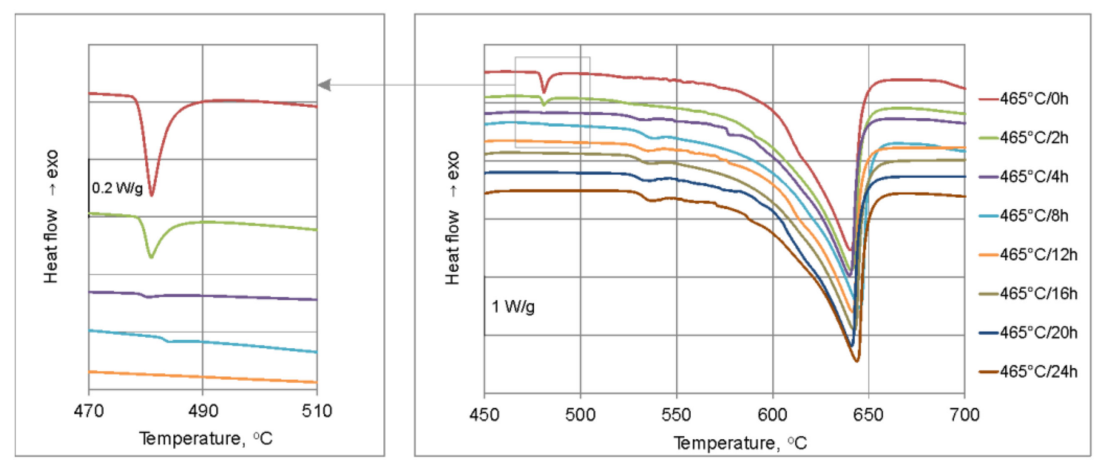

(d)

Figure 4. Exemplary DSC (Differential Scanning Calorimetry) curves of alloys subjected to homogenization: (a) 7075 alloy 1, standard homogenization; (b) 7075 alloy 2, high-temperature homogenization; (c) 7075 alloy 3, high-temperature homogenization; (d) 7049 alloy 4, standard homogenization.

In the case of alloy 1, the incipient melting peak observed on the DSC curve in the ascast state is found to decrease considerably already after $10 \mathrm{~h}$ of heating to $465{ }^{\circ} \mathrm{C}$. During soaking, it further diminishes, and after $4 \mathrm{~h}$ at the temperature of $465^{\circ} \mathrm{C}$, it vanishes. The solidus temperature rises to about $548^{\circ} \mathrm{C}$ and does not change with extending the soaking time to $8 \mathrm{~h}$ (Figures $4 \mathrm{a}$ and $5 \mathrm{a}$ ).

For alloy 2 (Figure $5 \mathrm{~b}$ ), after $2 \mathrm{~h}$ of soaking at $465^{\circ} \mathrm{C}$, the solidus temperature rises from about $483^{\circ} \mathrm{C}$ noted in the as-cast state to about $493^{\circ} \mathrm{C}$. Despite extending the soaking time at $465^{\circ} \mathrm{C}$ up to $24 \mathrm{~h}$, a small incipient melting peak is observed on the DSC curves, and the solidus temperature does not change noticeably, which means that the low-melting microstructure components are not fully dissolved. 


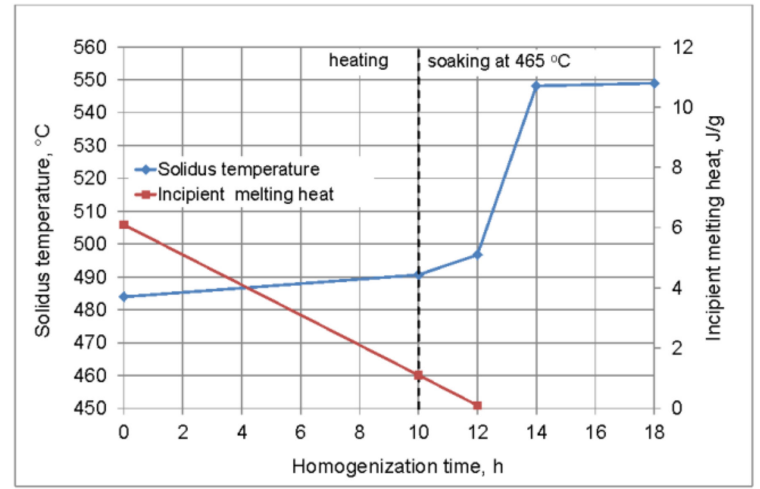

(a)

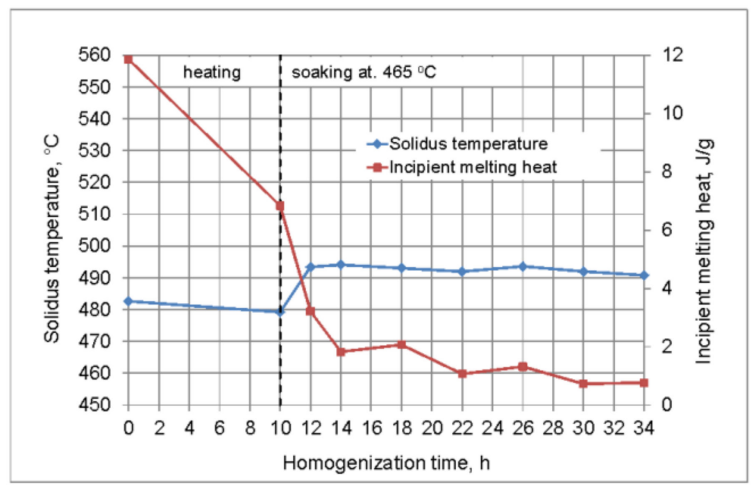

(b)

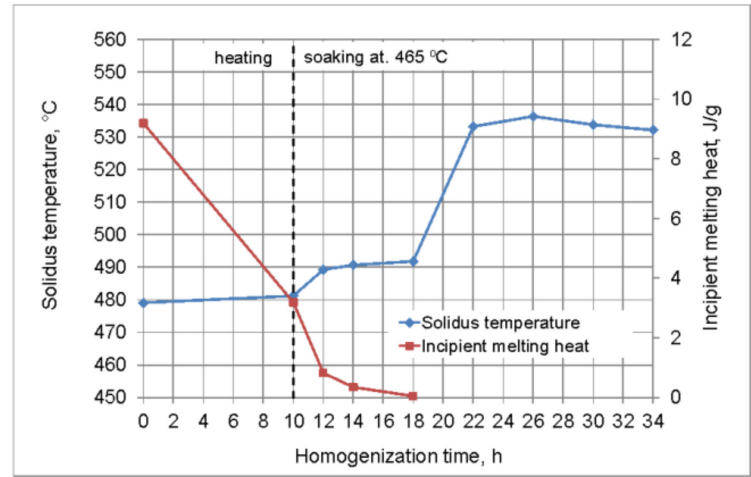

(d)

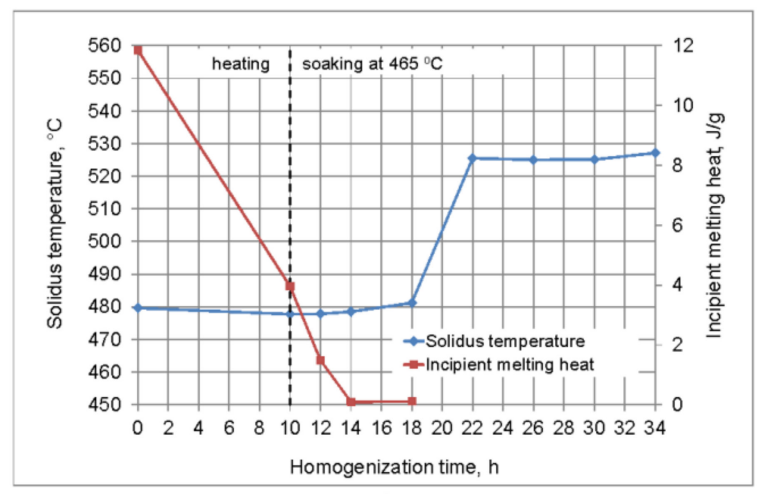

(f)

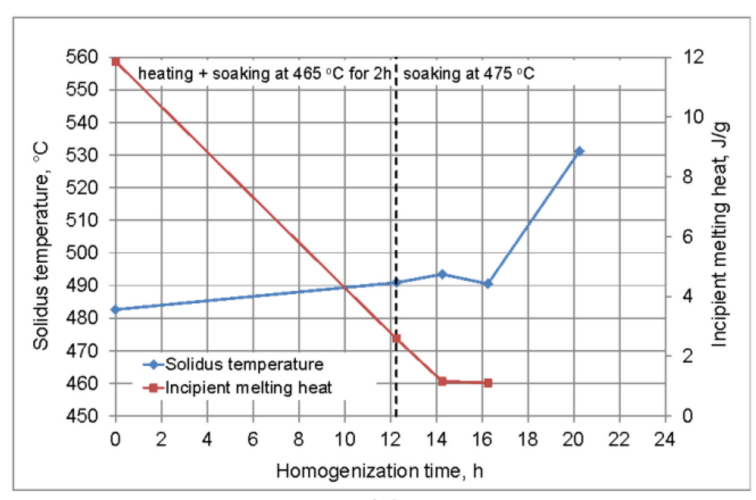

(c)

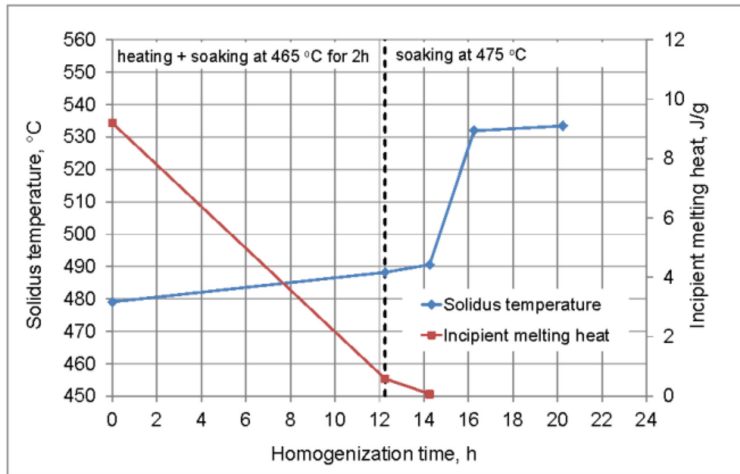

(e)

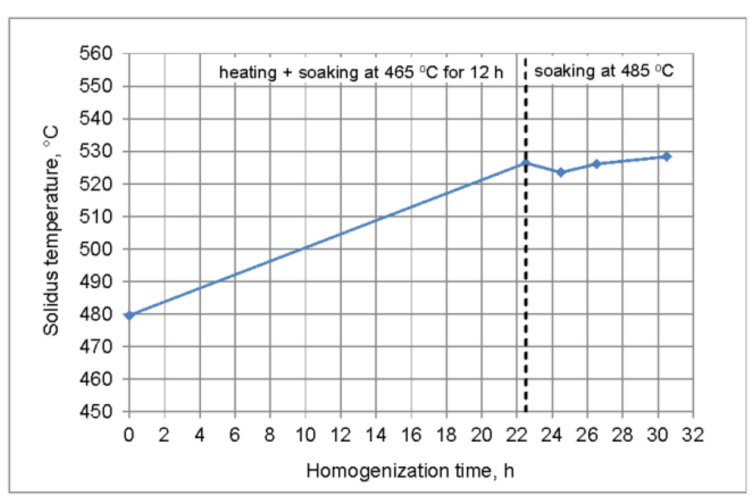

(g)

Figure 5. Changes of solidus temperature and incipient melting heat in the course of homogenization: (a) 7075 alloy 1 ; (b,c) 7075 alloy 2; (d,e) 7075 alloy 3; (f,g) 7049 alloy 4. Tables S1-S4 with determined values given in Supplementary Materials. 
The mentioned increase of solidus temperature after soaking at $465{ }^{\circ} \mathrm{C}$ for $2 \mathrm{~h}$ enabled the safe elevation of homogenization temperature to $475^{\circ} \mathrm{C}$. After $8 \mathrm{~h}$ of soaking at this temperature, the vanishing of incipient melting peak and the increase of solidus temperature to $531^{\circ} \mathrm{C}$ were noted (Figures $4 \mathrm{~b}$ and $5 \mathrm{c}$ ).

In the initial stages of alloy 3 homogenization at the temperature of $465^{\circ} \mathrm{C}$, the course of solidus temperature and incipient melting heat changes is similar to the one described for alloy 2. However, after soaking for 4 and $8 \mathrm{~h}$, very low values of incipient melting heat are noted (Figure $5 \mathrm{~d}$ ). After $12 \mathrm{~h}$ of soaking, i.e., after $22 \mathrm{~h}$ of homogenization, the peak vanishes, and the solidus temperature rises from about $490^{\circ} \mathrm{C}$ to about $534^{\circ} \mathrm{C}$. Similarly as for alloy 2 , the rise of solidus temperature observed after $2 \mathrm{~h}$ of soaking allowed for the application of higher homogenization temperature $-475^{\circ} \mathrm{C}$. The complete dissolution of low-melting microstructure components was achieved after $4 \mathrm{~h}$ of soaking at mentioned temperature, i.e., after slightly above $16 \mathrm{~h}$ of homogenization (Figures $4 \mathrm{c}$ and $5 \mathrm{e}$ ).

In the case of 7049 alloy 4 , within the $8 \mathrm{~h}$ of soaking at the temperature of $465{ }^{\circ} \mathrm{C}$, no changes of solidus temperature, with respect to as-cast state, are noted. However, the noticeable decrease of incipient melting heat is observed, particularly during heating and early stages of soaking. After the $12 \mathrm{~h}$ peak vanishes, the solidus temperature increases from about $479{ }^{\circ} \mathrm{C}$ to about $525^{\circ} \mathrm{C}$, and with prolonged soaking, it does not change (Figures $4 \mathrm{~d}$ and $5 \mathrm{f}$ ). Making use of observed increase of solidus temperature, a high-temperature homogenization with soaking at $485^{\circ} \mathrm{C}$ was accomplished. However, no changes of solidus temperature are noted when compared to standard homogenization (Figure $5 \mathrm{~g}$ ).

The microstructure of alloys 1-3 within 7075 grade was firstly examined after early homogenization stages, for which the initial increase of solidus temperature was noted. Although the dendrites are still visible (Figure 6a), we observed a considerable decrease in the fraction of second phase particles at dendrites/grains boundaries as well as an equilibration of the main alloying elements concentration in the dendrites/grains interiors (see Supplementary Materials, Figure $\mathrm{S1}$ ). The phase containing $\mathrm{Al}, \mathrm{Zn}, \mathrm{Mg}$, and $\mathrm{Cu}$ is not found, but besides $\mathrm{Mg}_{2} \mathrm{Si}$ as well as $\mathrm{Al}, \mathrm{Fe}$, and Cu-rich phases, the particles containing $\mathrm{Al}, \mathrm{Cu}$, and $\mathrm{Mg}$ are present (Figure 7). Based on microanalyses results, in particular, the Cu:Mg ratio close to 1 and the literature data mentioned earlier $[9,13,19,20]$, it is expected that this is the $\mathrm{S}-\mathrm{Al}_{2} \mathrm{CuMg}$ phase. The solidus temperature noted at this stage of soaking, about $490^{\circ} \mathrm{C}$ (Figure 5), is also within the range of reported solidus of $\mathrm{AlZnMgCu}$ alloys with the S-phase present in the microstructure $[12,14,15,21,26]$.

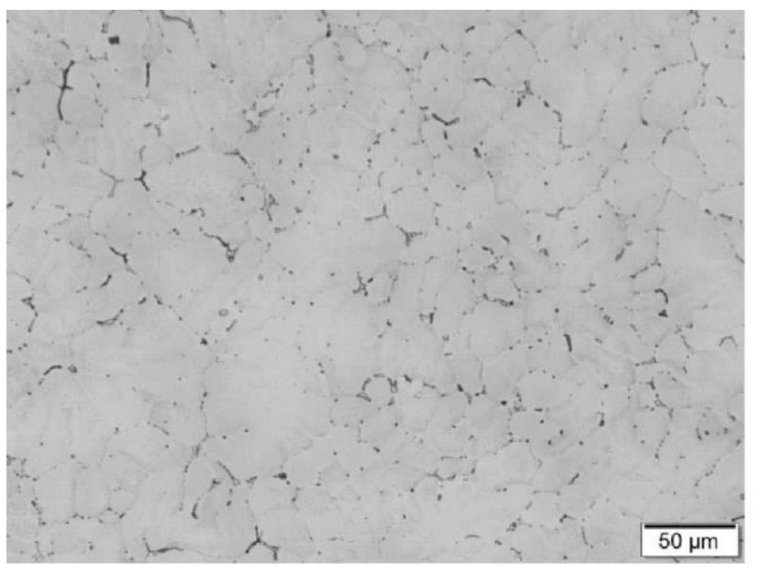

(a)

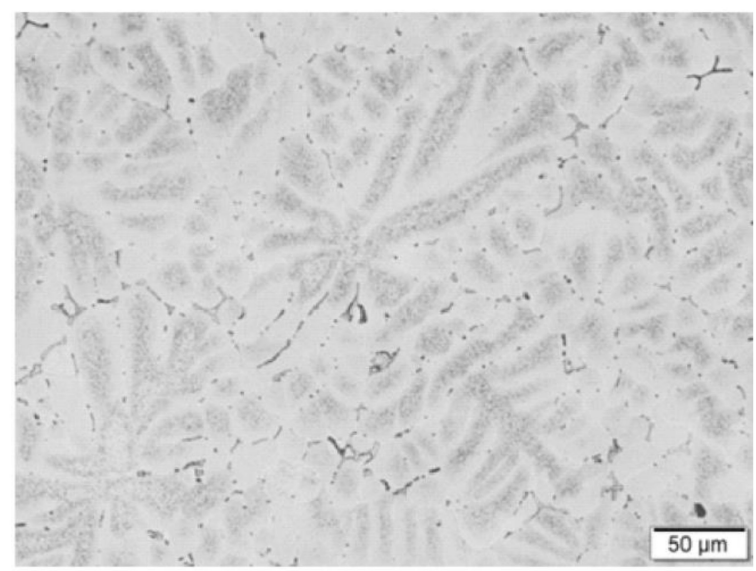

(b)

Figure 6. Exemplary microstructure of 7075 alloy 3 after homogenization: (a) soaking at $465{ }^{\circ} \mathrm{C}$ for 2 h; (b) soaking at $475{ }^{\circ} \mathrm{C}$ for $4 \mathrm{~h}$ (visible dispersoids reflecting former dendritic microstructure). 


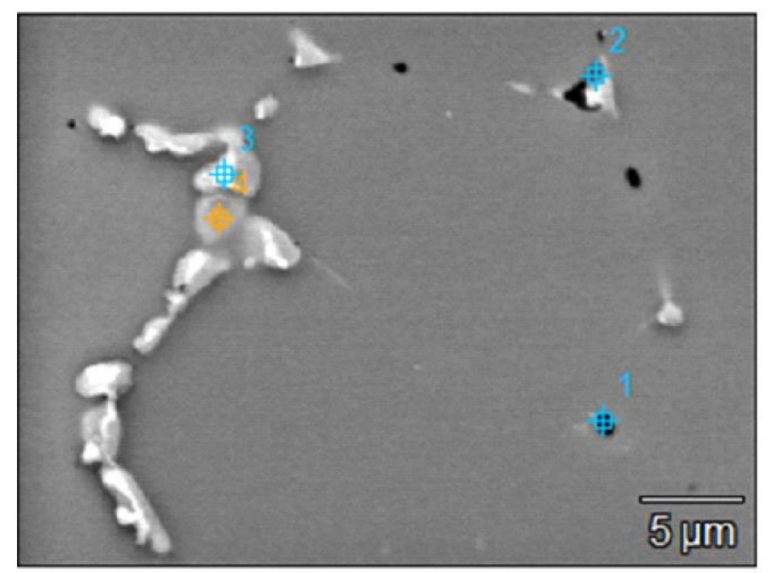

\begin{tabular}{|c|c|c|c|c|c|c|c|}
\hline \multicolumn{7}{|c|}{ Elements concentration, at. \%. } \\
\hline Area & $\mathrm{Mg}$ & $\mathrm{Al}$ & $\mathrm{Si}$ & $\mathrm{Cr}$ & $\mathrm{Fe}$ & $\mathrm{Cu}$ & $\mathrm{Zn}$ \\
\hline 1 & 16.8 & 68.8 & 11.6 & 0.1 & 0.2 & 0.6 & 1.9 \\
\hline 2 & 25.8 & 55.9 & 13.5 & & 0.6 & 3.0 & 1.0 \\
\hline 3 & 19.7 & 53.4 & 0.1 & & 0.6 & 24.4 & 1.8 \\
\hline 4 & 17.6 & 59.1 & & 0.1 & & 21.3 & 2.0 \\
\hline
\end{tabular}

Figure 7. Particles of phase $\mathrm{S}-\mathrm{Al}_{2} \mathrm{CuMg}$ and $\mathrm{Mg}_{2} \mathrm{Si}, 7075$ alloy 2 after soaking at $465^{\circ} \mathrm{C}$ for $2 \mathrm{~h}$.

In the alloys microstructure examined after homogenization variants, for which an incipient melting peak vanished, a low fraction of second-phase particles is observed (Figure $6 \mathrm{~b}$ ). In the most cases, only particles rich in $\mathrm{Al}, \mathrm{Fe}$, and $\mathrm{Cu}$ and phase $\mathrm{Mg}_{2} \mathrm{Si}$ are found (Figure 8). It should be noted here that the presence of the $\mathrm{Mg}_{2} \mathrm{Si}$ phase in the homogenized billets of described alloys is reported in the literature $[9,25]$. The distribution of main alloying elements in grains interiors is also most often sufficiently uniform (Figure S2).

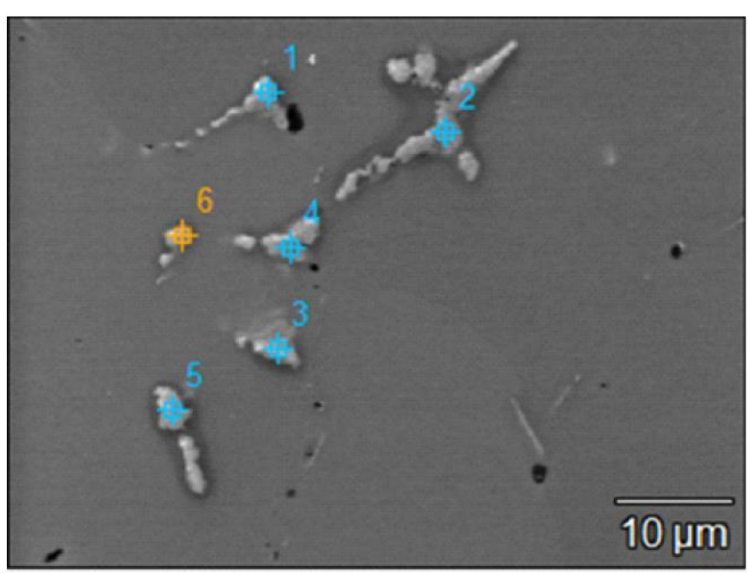

\begin{tabular}{|c|c|c|c|c|c|c|c|}
\hline \multicolumn{7}{|c|}{ Elements concentration, at. \% } \\
\hline Area & $\mathrm{Mg}$ & $\mathrm{Al}$ & $\mathrm{Si}$ & $\mathrm{Cr}$ & $\mathrm{Fe}$ & $\mathrm{Cu}$ & $\mathrm{Zn}$ \\
\hline 1 & 1.0 & 75.9 & & 0.1 & 6.6 & 15.4 & 1.0 \\
\hline 2 & 0.4 & 70.9 & & 0.1 & 8.6 & 19.3 & 0.8 \\
\hline 3 & 0.3 & 74.8 & & 0.1 & 7.3 & 16.2 & 1.2 \\
\hline 4 & & 68.4 & 0.1 & 0.1 & 9.5 & 21.0 & 0.9 \\
\hline 5 & & 69.3 & & 0.1 & 8.3 & 21.6 & 0.6 \\
\hline 6 & 0.8 & 76.4 & 0.2 & 0.4 & 8.0 & 13.4 & 0.8 \\
\hline
\end{tabular}

Figure 8. Examples of particles containing $\mathrm{Al}, \mathrm{Cu}$, and $\mathrm{Fe}$ as well as $\mathrm{Mg}_{2} \mathrm{Si}$ in observed in the microstructure of 7075 alloy 2 after soaking at $475^{\circ} \mathrm{C}$ for $8 \mathrm{~h}$.

\subsection{Cooling from Homogenization Temperature}

In the case of leanest alloy 1, the DSC curves after all examined cooling manners are very similar (Figure 9a). No incipient melting peaks are observed, and the solidus temperature is much the same as the one obtained after homogenization with water quenching (Table 4). For alloy 4 with high Zn content, only after the slowest cooling from the homogenization temperature on the DSC curve is a small peak observed with the onset at the temperature of $481^{\circ} \mathrm{C}$ (Figure 9c). This value is similar to solidus temperature of that alloy in the as-cast state $\left(480^{\circ} \mathrm{C}\right)$. The low incipient melting heat indicates that the fraction of undissolved particles in the microstructure is rather small (Table 4). The values of solidus temperature after two other cooling manners are in agreement with those noted after water quenching. In the case of alloy 2 with the highest $\mathrm{Cu}$ concentration, after cooling at 500 and $120^{\circ} \mathrm{C} / \mathrm{h}$ on DSC curves, incipient melting peaks with onset at about $491-495^{\circ} \mathrm{C}$ are present (Figure 9b). For the slowest cooling, two peaks are observed with onsets at 478 and 
$491{ }^{\circ} \mathrm{C}$. The onset temperature of $478^{\circ} \mathrm{C}$ is only slightly lower than that noted for this alloy in the as-cast state. The peaks at about $490-494{ }^{\circ} \mathrm{C}$ were observed during homogenization soaking, when the S-phase was observed in the alloy microstructure.

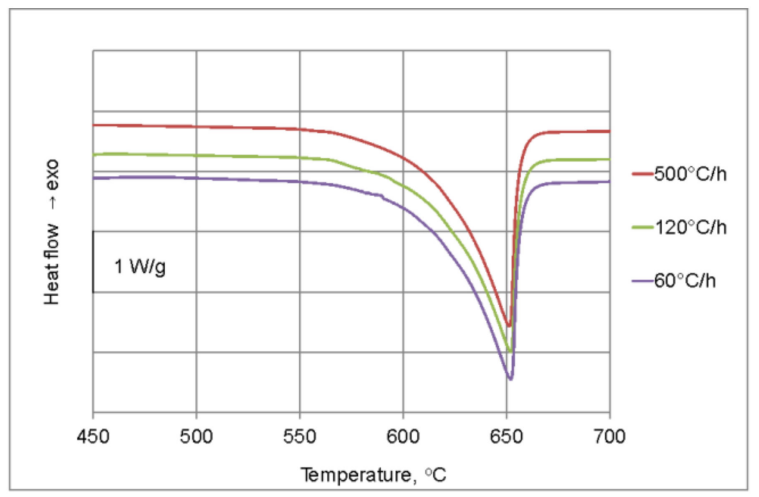

(a)
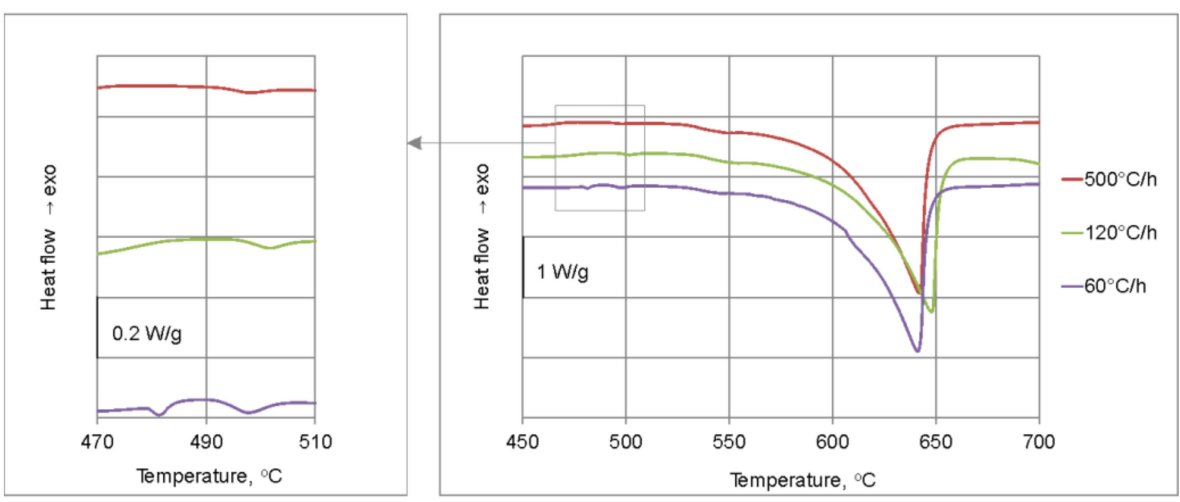

(b)
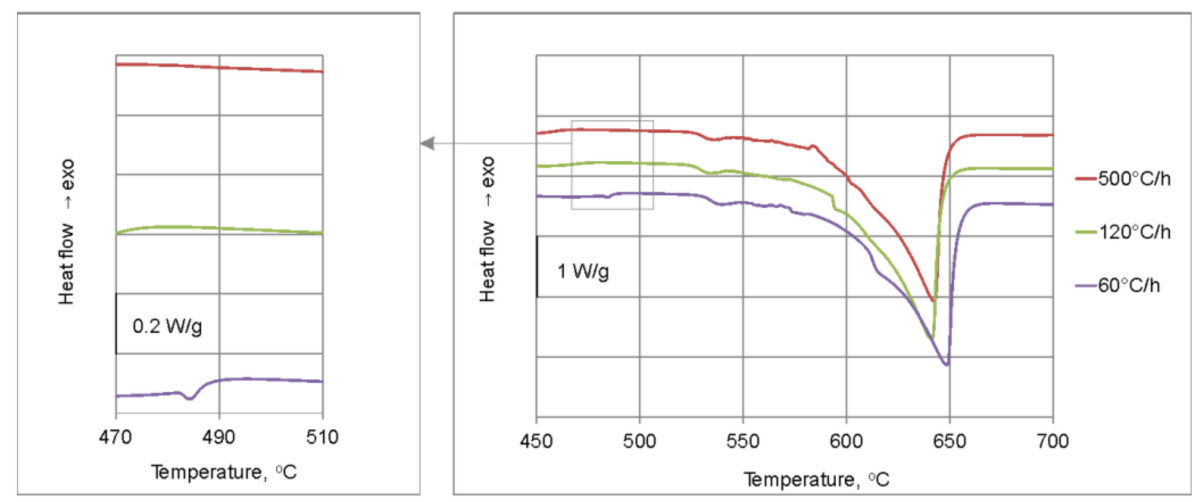

(c)

Figure 9. DSC curves of alloys subjected to various cooling rates from homogenization temperature: (a) 7075 alloy 1 after homogenization with soaking at $465^{\circ} \mathrm{C}$ for $4 \mathrm{~h}$; (b) 7075 alloy 2 after homogenization with final soaking at $475^{\circ} \mathrm{C}$ for $8 \mathrm{~h}$; (c) 7049 alloy 4 after homogenization with soaking at $465^{\circ} \mathrm{C}$ for $12 \mathrm{~h}$. 
Table 4. DSC tests results of alloys 1, 2, and 4 after homogenization with differentiated cooling.

\begin{tabular}{|c|c|c|c|}
\hline Alloy & Cooling Rate & Solidus Temperature ${ }^{1},{ }^{\circ} \mathrm{C}$ & Incipient Melting Heat ${ }^{1}, \mathrm{~J} / \mathrm{g}$ \\
\hline \multirow{3}{*}{$\begin{array}{c}7075 \text { alloy } 1 \\
\text { soaking } 465^{\circ} \mathrm{C} / 4 \mathrm{~h}\end{array}$} & $500^{\circ} \mathrm{C} / \mathrm{h}$ & 545.7 & \\
\hline & $120^{\circ} \mathrm{C} / \mathrm{h}$ & 547.0 & \\
\hline & $60^{\circ} \mathrm{C} / \mathrm{h}$ & 547.7 & \\
\hline \multirow{3}{*}{$\begin{array}{c}7075 \text { alloy } 2 \\
\text { soaking } 475^{\circ} \mathrm{C} / 8 \mathrm{~h}\end{array}$} & $500^{\circ} \mathrm{C} / \mathrm{h}$ & 491.3 & 0.3 \\
\hline & $120^{\circ} \mathrm{C} / \mathrm{h}$ & 495.0 & 0.5 \\
\hline & $60^{\circ} \mathrm{C} / \mathrm{h}$ & $478.0 / 490.9$ & $0.3 / 0.8$ \\
\hline \multirow{3}{*}{$\begin{array}{c}7049 \text { alloy } 4 \\
\text { soaking } 465^{\circ} \mathrm{C} / 12 \mathrm{~h}\end{array}$} & $500^{\circ} \mathrm{C} / \mathrm{h}$ & 524.6 & \\
\hline & $120^{\circ} \mathrm{C} / \mathrm{h}$ & 523.4 & \\
\hline & $60^{\circ} \mathrm{C} / \mathrm{h}$ & 481.3 & 0.3 \\
\hline
\end{tabular}

${ }^{1}$ In the case of alloy 2 cooled at $60^{\circ} \mathrm{C} / \mathrm{h}$ onsets and heat values for both observed peaks are given.

The SEM/EDS microanalyses of alloys after homogenization with cooling at $60{ }^{\circ} \mathrm{C} / \mathrm{h}$ show that in the case of alloys 1 and 4, a precipitation of particles containing $\mathrm{Al}, \mathrm{Zn}, \mathrm{Mg}$, and usually $\mathrm{Cu}$ took place (Figure 10b). The above-described dissimilarity in the DSC test results for these alloys may be an effect of different phases' precipitation, larger particle sizes for alloy 4, and the values of the alloys' solvus temperature. One may expect that the lean 7075 alloy 1 has a noticeably lower solvus temperature. Thus, for this alloy, the time for complete particles dissolution during the test was longer, and even particles that precipitated in the course of very slow cooling could be dissolved during subsequent heating. In the microstructure of alloy 2, the particles with the same components, i.e., $\mathrm{Al}$, $\mathrm{Zn}, \mathrm{Mg}$, and most often $\mathrm{Cu}$ are also present, but additionally, the S-phase particles are found (Figure 10a).

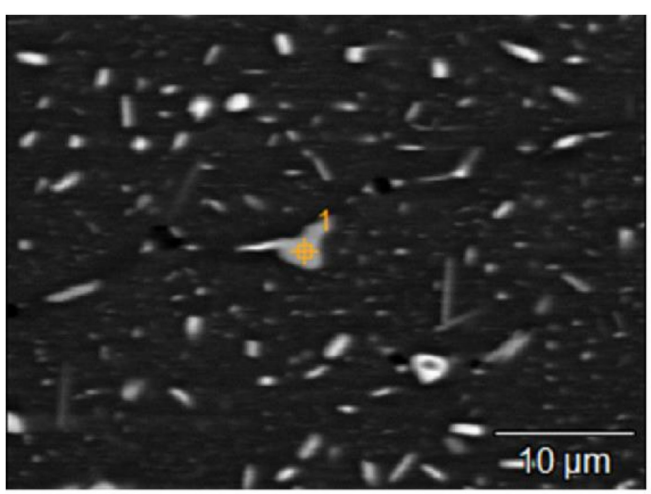

\begin{tabular}{|c|c|c|c|c|}
\hline \multicolumn{5}{|c|}{ Elements concentration, at. \% } \\
\hline Area & $\mathrm{Mg}$ & $\mathrm{Al}$ & $\mathrm{Cu}$ & $\mathrm{Zn}$ \\
\hline 1 & 19.3 & 57.9 & 21.1 & 1.7 \\
\hline
\end{tabular}

(a)

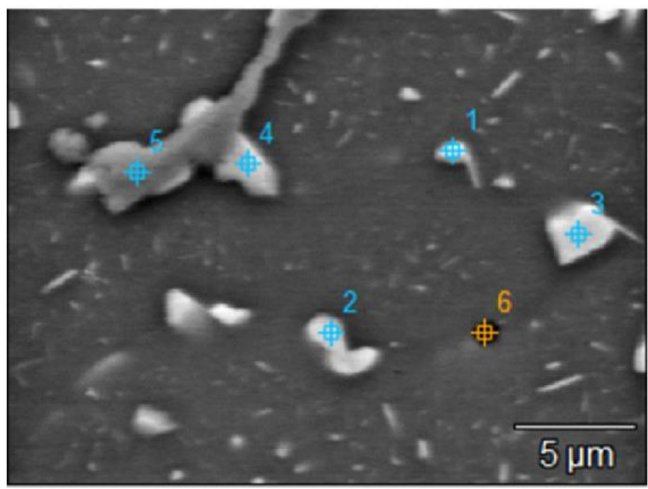

\begin{tabular}{|c|c|c|c|c|c|c|}
\hline \multicolumn{7}{|c|}{ Elements concentration, at. \% } \\
\hline Area & $\mathrm{Mg}$ & $\mathrm{Al}$ & $\mathrm{Si}$ & $\mathrm{Fe}$ & $\mathrm{Cu}$ & $\mathrm{Zn}$ \\
\hline 1 & 11.0 & 65.0 & & 0.6 & 4.7 & 18.7 \\
\hline 2 & 11.4 & 66.5 & & & & 22.2 \\
\hline 3 & 30.8 & 21.0 & & & 9.9 & 38.3 \\
\hline 4 & 23.7 & 37.4 & & & 7.5 & 31.4 \\
\hline 5 & 0.6 & 72.2 & & 8.6 & 18.4 & \\
\hline 6 & 10.5 & 77.1 & 9.1 & & 0.5 & 2.9 \\
\hline
\end{tabular}

(b)

Figure 10. Particles observed in the alloys microstructure after cooling from the homogenization temperature at $60{ }^{\circ} \mathrm{C} / \mathrm{h}$ : (a) 7075 alloy 2; (b) 7049 alloy 4 . 
Taking these observations into consideration, together with the presented above remarks regarding the solidus temperature, the DSC results for various cooling conditions may be explained as follows: After cooling of alloys 2 and 4 at $60^{\circ} \mathrm{C} / \mathrm{h}$, the incipient melting is caused by the same phase(s) containing $\mathrm{Al}, \mathrm{Zn}, \mathrm{Mg}$, and $\mathrm{Cu}$, which were observed in the as-cast state. For alloy 2 cooled at 120 and $500{ }^{\circ} \mathrm{C} / \mathrm{h}$, the solidus results from presence in the microstructure of the S-phase, which also initiated the melting in a partially homogenized state. The mentioned slight discrepancy in onset temperature between the as-cast state and after cooling at the lowest rate may result from differences in the composition of phases formed in non-equilibrium and equilibrium conditions.

\section{Discussion}

In the case of all examined alloys, the low-melting microstructure components were dissolved during homogenization soaking in a degree sufficient in practice-no incipient melting peaks on the DSC curves are noted. As a result, the significant increase of solidus temperature was achieved, and the obtained values are within the range from $525{ }^{\circ} \mathrm{C}$ for alloy 4 to $548^{\circ} \mathrm{C}$ for alloy 1 (Table 5).

Table 5. Homogenization soaking parameters enabling maximizing the solidus temperature.

\begin{tabular}{ccc}
\hline Alloy & Soaking & Solidus Temperature, ${ }^{\circ} \mathrm{C}$ \\
\hline 7075 alloy 1 & $465^{\circ} \mathrm{C} / 4 \mathrm{~h}$ & 548.1 \\
7075 alloy 2 & $465{ }^{\circ} \mathrm{C} / 2 \mathrm{~h}+475^{\circ} \mathrm{C} / 8 \mathrm{~h}$ & 531.2 \\
7075 alloy 3 & $465^{\circ} \mathrm{C} / 12 \mathrm{~h}$ & 533.2 \\
7049 alloy 4 & $465{ }^{\circ} \mathrm{C} / 2 \mathrm{~h}+475^{\circ} \mathrm{C} / 4 \mathrm{~h}$ & 531.9 \\
\hline
\end{tabular}

For alloys 1, 2, and 3 of 7075 grade, the low-melting components are in sequence: phase(s) containing $\mathrm{Al}, \mathrm{Zn}, \mathrm{Mg}$, and $\mathrm{Cu}$ observed in the as-cast state, and after their dissolution in the early annealing stages, it is the phase $\mathrm{S}$. In the case of alloys 1 and 3 , the expected results are obtained after homogenization at a temperature of $465{ }^{\circ} \mathrm{C}$ with soaking time of 4 and $12 \mathrm{~h}$, respectively. This is a rather low soaking temperature when compared to literature data $[9,14,20,21]$. It should be mentioned here that in many papers, e.g., $[12,15,25,27,28]$, only a significant decrease of low-melting phases content is described. The soaking time for alloy 1 can be assessed as very short, which results from low main alloying additions concentration. For alloy 3, with high $\mathrm{Zn}$ and medium $\mathrm{Mg}$ and $\mathrm{Cu}$ content (with respect to grade limits), it is three times longer, but it is still acceptable in the industrial practice. However, the application of higher temperature in the second soaking stage enables the shortening of total annealing time from 22 to about $16 \mathrm{~h}$. In the case of alloy 2 with highest $\mathrm{Cu}$ content, the DSC test results after standard homogenization show the presence of phase $S$ after soaking for 2 to $24 \mathrm{~h}$. The incipient melting heat changes indicate that at this temperature, the dissolution of the S-phase is probably unattainable. Therefore, the application of high-temperature homogenization with soaking at $475^{\circ} \mathrm{C}$ was necessary. As it was mentioned above, in all alloys of 7075 grade, the incipient melting in the course of homogenization (after initial solidus increase) is caused by the presence in the microstructure of the same phase $S$, and only for alloy 2 is the high-temperature homogenization required for its dissolution. Based on the phase diagram [26], one may expect that this discrepancy results from the fact that for alloy 2, the S-phase solvus is above $465{ }^{\circ} \mathrm{C}$.

The DSC curves of alloy 4, with composition of 7049 grade, indicate that during homogenization soaking at the temperature of $465{ }^{\circ} \mathrm{C}$ for at least $8 \mathrm{~h}$, the incipient melting results from the presence of the same phase(s) as in the as-cast state i.e., containing $\mathrm{Al}, \mathrm{Zn}$, $\mathrm{Mg}$, and $\mathrm{Cu}$. The dissolution of low-melting microstructure components was noted after of $12 \mathrm{~h}$ soaking. The lack of solidus temperature change as a result of longer homogenization at $465{ }^{\circ} \mathrm{C}$, as well as after homogenization with soaking at $485^{\circ} \mathrm{C}$ (Figure $5 \mathrm{f}, \mathrm{g}$ ), allows stating that for billets of this alloy, the mentioned standard homogenization is sufficient. 
The obtained results clearly indicate that the cooling from the homogenization temperature may have an essential influence on the billets microstructure and solidus temperature. This is consistent with the literature data $[9,14]$. However, the present work shows that the effect of cooling rate is strongly dependent on alloy composition, and significant differences can be observed even within one grade. This observation, to the authors' knowledge, is not described in the literature.

The billets of 7075 alloy 1 can be cooled very slowly without influencing the solidus temperature. In contrary, in the case of 7075 alloy 2, the lowering of solidus temperature is observed also in spite of fast cooling, at $500{ }^{\circ} \mathrm{C} / \mathrm{h}$. This results from the fact that during cooling from the homogenization temperature, the S-phase precipitates. As it was mentioned above, for this composition, the S-phase solvus temperature is high-the soaking investigations allow expecting that it is within the range of 465 to $475{ }^{\circ} \mathrm{C}$. In addition, during rapid heating applied in this work, the time for particles dissolution is found to be too short, despite their small dimensions obtained as a result of fast cooling. In industrial practice, the billet preheating takes significantly longer. However, the billets are usually preheated to a temperature below the estimated above S-phase solvus [7], and a further temperature increase during extrusion may be fast. The obtained result indicates that for alloy 2, the application of fast billets cooling, within limitations resulting for example from billets dimensions, may be insufficient for taking advantage of the solidus increase obtained during soaking. In this case, special attention should be paid to billets preheating in order to ensure that the S-phase will not cause the incipient melting during the extrusion, with a significant temperature increase in a welding chamber. For example, the slow billets preheating to the temperature slightly above the S-phase solvus but below $490^{\circ} \mathrm{C}$ (where melting is noted) may be applied with short holding if necessary. Then, if the mentioned temperature is too high from the point of view of extrusion parameters, the billets (short, already cut to desired length) may be fast cooled to the needed temperature. A similar billets preheating manner is described for 6xxx alloys [29].

In the case of high-Zn 7049 alloy 4, for which the precipitation of phase(s) containing $\mathrm{Al}, \mathrm{Zn}, \mathrm{Mg}$, and $\mathrm{Cu}$ is noted, it is sufficient to cool the billets from homogenization temperature at moderate rate of $120^{\circ} \mathrm{C} / \mathrm{h}$. The precipitated particles are able to dissolve during subsequent rapid heating, and the high solidus temperature of $525^{\circ} \mathrm{C}$ is maintained.

\section{Conclusions}

On the basis of the obtained results, the following conclusions can be drawn:

1. In the case of all examined AlZnMgCu alloys, the low-melting microstructure components present in the as-cast state or formed in the initial stage of homogenization were dissolved during soaking. As a result, the significant increase of solidus temperature was achieved. The obtained values were within the range of 525 to $548{ }^{\circ} \mathrm{C}$, depending on alloy composition.

2. For two of the investigated 7075 alloys and 7049 alloy, covering a broad Zn concentration range and characterized by low to medium $\mathrm{Mg}$ and $\mathrm{Cu}$ content, the homogenization at the temperature of $465^{\circ} \mathrm{C}$ was sufficient for achieving the mentioned solidus increase. The two-step soaking with a final temperature of $475^{\circ} \mathrm{C}$ may be useful for reducing the annealing time. The application of high-temperature homogenization was found to be necessary only for the alloy 7075 with increased $\mathrm{Cu}$ content.

3. In order to take advantage of the high solidus temperature obtained after soaking, the cooling rate from homogenization must be appropriately selected, and the effective cooling manner is strongly dependent on the alloy composition. In particular, for 7049 alloy, the application of a moderate cooling rate from a homogenization temperature of about $120{ }^{\circ} \mathrm{C} / \mathrm{h}$ is sufficient. In the case of high-Cu 7075 alloy, despite the fast cooling, the lowering of solidus temperature was noted. In this case, the dissolution of the S-phase causing this effect must be ensured during careful billets preheating. 
Supplementary Materials: The following are available online at https:/ /www.mdpi.com/2075-470 1/11/2/338/s1, Figure S1: Exemplary distribution of main alloying additions in dendrites/grains interiors in initial stage of homogenization, 7075 alloy 3 after soaking at $465^{\circ} \mathrm{C}$ for $2 \mathrm{~h}$, Figure S2: Exemplary distribution of main alloying additions in grains interiors after homogenization: (a) 7075 alloy 2 after soaking at $475{ }^{\circ} \mathrm{C}$ for $8 \mathrm{~h}$; (b) 7049 alloy 4 after soaking at $465^{\circ} \mathrm{C}$ for $12 \mathrm{~h}$, Figure S3: Dispersoids in 7075 alloy 3 after homogenization: (a) standard, with soaking at $465{ }^{\circ} \mathrm{C}$ for $12 \mathrm{~h}$; (b) high-temperature, with final soaking at $475{ }^{\circ} \mathrm{C}$ for $4 \mathrm{~h}$, Figure S4: Microstructure of alloys subjected to various cooling from homogenization temperature: (a-c) 7049 alloy 4 cooled at 500, 120, and $60{ }^{\circ} \mathrm{C} / \mathrm{h}$ respectively; (d) 7075 alloy 1 cooled at $60^{\circ} \mathrm{C} / \mathrm{h}$, Table S1: 7075 alloy 1, DSC test results after examined soaking variants., Table S2: 7075 alloy 2, DSC test results after examined soaking variants., Table S3: 7075 alloy 3, DSC test results after examined soaking variants., Table S4. 7049 alloy 4, DSC test results after examined soaking variants.

Author Contributions: Conceptualization, A.W. and G.W. methodology, A.W.; investigation, J.M., B.L.-M., J.G. and G.W.; writing-original draft preparation, A.W.; writing-review and editing, G.W., B.L.-M., J.G., J.M. and D.L.; supervision, D.L. All authors have read and agreed to the published version of the manuscript.

Funding: This research was funded by THE NATIONAL CENTRE FOR RESAERCH AND DEVELOPMENT, grant number TECHMATSTRATEG2/406439/10/NCBR/2019 “Extrusion welding of high-strength shapes from aluminium alloys 7xxx series".

Data Availability Statement: Not applicable.

Acknowledgments: The authors are grateful to Józef Zasadziński and Wojciech Libura for valuable discussions during investigations and results analysis.

Conflicts of Interest: The authors declare no conflict of interest.

\section{References}

1. Leśniak, D. Weldability Investigations of AlCuMg Alloys for Extrusion Welding. Arch. Met. Mater. 2012, 57, 7-17. [CrossRef]

2. Wojtyna, A.; Leśniak, D.; Rękas, A.; Latos, T.; Zaborowski, K.; Leszczyńska-Madej, B. Analysis of Extrusion Welding Conditions for AlMg Alloys with High Mg Content. Key Eng. Mater. 2016, 682, 401-407. [CrossRef]

3. Duplancic, I.; Prgin, J. Determination of parameters required for joining process in hollow dies. In Proceedings of the 6th International Aluminium Extrusion Technology Seminar, Chicago, IL, USA, 14-17 May 1996; pp. 225-230.

4. Gasiorczyk, J.; Richert, J. Application of FEM modeling to simulate metal flow through porthole dies. In Proceedings of the 7th Aluminium Extrusion Technology Seminar, Chicago, IL, USA, 16-19 May 2000; pp. 195-202.

5. Khan, Y.A.; Valberg, H.; Irgens, I. Joining of metal streams in extrusion welding. Int. J. Mater. Form. 2009, 2, 109-112. [CrossRef]

6. Leśniak, D.; Gromek, P. Estimation of Extrusion Welding Conditions for 6xxx Aluminum Alloys. Procedia Manuf. 2020, 47, 253-260. [CrossRef]

7. Dixon, B. Extrusion of 2xxx and 7xxx Alloys. In Proceedings of the 7th International Aluminum Extrusion Technology Seminar, Chicago, IL, USA, 16-19 May 2011; pp. 281-294.

8. Sheppard, T. Extrusion of Aluminium Alloys; Springer International Publishing: Berlin/Heidelberg, Germany, 1999 ; pp. $205-252$.

9. Jackson, A.; Sheppard, T. Structural Modifications Occurring during Homogenization of Some 7xxx Alloys. In Proceedings of the 6th International Aluminum Extrusion Technology Seminar, Chicago, IL, USA, 14-17 May 1996; Aluminum Association and Aluminum Extruders Council: Wauconda, IL, USA, 1996; Volume 1, pp. 541-550.

10. Belov, N.A.; Eskin, D.G.; Aksenov, A.A. Multicomponent Phase Diagrams, Applications for Commercial Aluminum Alloys; Elsevier: London, UK, 2005.

11. Lim, S.T.; Eun, I.S.; Nam, S.W. Control of Equilibrium Phases (M,T,S) in the Modified Aluminum Alloy 7175 for Thick Forging Applications. Mater. Trans. 2003, 44, 181-187. [CrossRef]

12. Chen, H.; Gao, X.; Rometsch, P.; Xu, D.; Muddle, B. Dissolution and melting of constituent particles in a DC-cast Al-Zn-Mg-Cu alloy 7150 during homogenisation. In Proceedings of the 12th International Conference on Aluminium Alloys, Yokohama, Japan, 5-9 September 2010; Kumai, S., Umezawa, O., Takayama, Y., Tsuchida, T., Sato, T., Eds.; Institute of Light Metals: Yokohama, Japan, 2010; pp. 1656-1661.

13. Fan, X.; Jiang, D.; Meng, Q.; Zhong, L. The microstructural evolution of an Al-Zn-Mg-Cu alloy during homogenization. Mater. Lett. 2006, 60, 1475-1479. [CrossRef]

14. Wang, L.J.; Xu, D.K.; Rometsch, P.A.; Gao, S.X.; Zhang, Y.; He, Z.B.; Couper, M.J.; Muddle, B.C. Effect of Homogenisation Parameters on Dissolution and Precipitation in Aluminium Alloy AA7150. Mater. Sci. Forum 2011, 693, 276-281. [CrossRef]

15. Fan, X.-G.; Jiang, D.-M.; Meng, Q.-C.; Zhang, B.-Y.; Wang, T. Evolution of eutectic structures in Al-Zn-Mg-Cu alloys during heat treatment. Trans. Nonferrous Met. Soc. China 2006, 16, 577-581. [CrossRef] 
16. Senatorova, O.G.; Bronz, A.V.; Cheverikin, V.V.; Somov, A.V.; Blinova, N.E. Study of the Structure and Properties of Especially Strong Aluminum Alloys of the Al-Zn-Mg-Cu System. Metallurgist 2017, 60, 978-982. [CrossRef]

17. Bäckerud, L.; Król, E.; Tamminen, J.; Skanaluminium American Foundrymen's Society. Solidification Characteristics of Aluminium Alloys: Wrought Alloys; Skanaluminium, Universitetsforlaget AS: Oslo, Norway, 1986; Volume 1.

18. Shu, W.X.; Hou, L.G.; Liu, J.C.; Zhang, C.; Zhang, F.; Liu, J.T.; Zhuang, L.Z.; Zhang, J.S. Solidification Paths and Phase Components at High Temperatures of High-Zn Al-Zn-Mg-Cu Alloys with Different Mg and Cu Contents. Met. Mater. Trans. A 2015, 46, 5375-5392. [CrossRef]

19. Priya, P.; Johnson, D.R.; Krane, M.J. Modeling phase transformation kinetics during homogenization of aluminum alloy 7050. Comput. Mater. Sci. 2017, 138, 277-287. [CrossRef]

20. Ghosh, A.; Ghosh, M. Microstructure and texture development of 7075 alloy during homogenisation. Philos. Mag. 2018, 98, 1470-1490. [CrossRef]

21. Deng, Y.; Yin, Z.; Cong, F. Intermetallic phase evolution of 7050 aluminum alloy during homogenization. Intermetallics 2012, 26, 114-121. [CrossRef]

22. Woznicki, A.; Leśniak, D.; Włoch, G.; Leszczynska-Madej, B.; Wojtyna, A. The Effect Of Homogenization Conditions On The Structure And Properties Of 6082 Alloy Billets. Arch. Met. Mater. 2015, 60, 1763-1772. [CrossRef]

23. Woźnicki, A.; Leszczyńska-Madej, B.; Leśniak, D.; Włoch, G.; Pałka, P.; Wojtyna, A. The Effect of Cooling Rate after Homogenization on the Microstructure and Properties of 2017a Alloy Billets for Extrusion with Solution Heat Treatment on the Press. Arch. Metall. Mater. 2016, 61, 1663-1670. [CrossRef]

24. She, H.; Shu, D.; Chu, W.; Wang, J.; Sun, B. Microstructural Aspects of Second Phases in As-cast and Homogenized 7055 Aluminum Alloy with Different Impurity Contents. Met. Mater. Trans. A 2013, 44, 3504-3510. [CrossRef]

25. Mondal, C.; Mukhopadhyay, A. On the nature of T(Al2Mg3Zn3) and S(Al2CuMg) phases present in as-cast and annealed 7055 aluminum alloy. Mater. Sci. Eng. A 2005, 391,367-376. [CrossRef]

26. Li, X.M.; Starink, M.J. DSC Study on Phase Transitions and Their Correlation with Properties of Overaged Al-Zn-Mg-Cu Alloys. J. Mater. Eng. Perform. 2011, 21, 977-984. [CrossRef]

27. Chen, K.; Liu, H.; Zhang, Z.; Li, S.; Todd, R.I. The improvement of constituent dissolution and mechanical properties of 7055 aluminum alloy by stepped heat treatments. J. Mater. Process. Technol. 2003, 142, 190-196. [CrossRef]

28. Cong, F.-G.; Zhao, G.; Jiang, F.; Tian, N.; Li, R.-F. Effect of homogenization treatment on microstructure and mechanical properties of DC cast 7X50 aluminum alloy. Trans. Nonferrous Met. Soc. China 2015, 25, 1027-1034. [CrossRef]

29. Reiso, O.; Hafsås, J.E.; Sjothun, O.; Tundal, U. The Effect of Cooling Rate after Homogenization and Billet Preheating Practice on Extrudability and Section Properties. Part 1: Extrudability and Mechanical Properties. In Proceedings of the 6th International Aluminum Extrusion Technology Seminar, Chicago, IL, USA, 14-17 May 1996; Volume 1, pp. 1-10. 